\title{
CrimRxiv
}

\section{Credit and Trust:}

\section{Management of Network}

Ties in Illicit Drug

Distribution

Kim Moeller, Sveinung Sandberg

Published on: Jul 27, 2020

DOI: $10.21428 / \mathrm{cb} 6 \mathrm{ab} 371 . c 4307015$

License: Creative Commons Attribution-NonCommercial-NoDerivatives 4.0 International

License (CC-BY-NC-ND 4.0). 


\section{Abstract}

Objectives: This study examines the use of credit, or "fronting," in the illegal drug economy. We study how fronting affects transaction costs and insulates against law enforcement in drug distribution networks and what role fronting plays in the management of interpersonal network ties. The emphasis is on the cooperative dimension of credits. Methods: Qualitative interviews were conducted with 68 incarcerated drug dealers in Norwegian prisons. Most were mid-level dealers (66 percent), dealing with many different drugs, but amphetamines were the main drugs distributed (38 percent). Using qualitative content analysis, we explore their perspective on the fronting of illegal drugs and associated practices in the illegal drug economy. Results: We find that dealers are generally skeptical toward fronting drugs, and accepting fronted drugs, but that this practice still is common. The main reason is that the practice secures a faster turnaround. Credits are embedded in social relationships both economically and socially. Previous social relationships are often a prerequisite, but fronting is also used to build trust. Conclusion: Although transaction cost economics captures the economic dimension of credit, insights from economic sociology and in particular the social embeddedness approach are necessary to understand the interplay between economic and social factors when drugs are fronted in the illegal economy.

\section{Keywords}

rational choice theory, criminological theory, drug selling/trafficking, drugs, organized crime, qualitative research, research methods

\section{Introduction}

Credit eases transactions and stimulates demand. Contrary to money that is generalized, immediate, and transferable, credit is specific and defined by deferred repayment, and this raises problems of trust. In the legal economy, this problem is ameliorated by the use of credit ratings that summarize relevant information on potential debtors such as payment history, income, and concurrent debts. Should the debtor default on repayment, creditors are also protected by a system of institutions, intricate contracting, and insolvency laws (Carruthers 2005; Carruthers and Kim 2011). Although there are good reasons for both taking and giving credit in the legal economy, it is more problematic in the illegal economy.

Jacques and Wright (2008) described credit under illegality as a non-predatory reciprocation that refers to a noncoercive, nonfraudulent, and bilateral giving and taking of resources between actors. The problem is that illegal markets exist in dynamic social environments where laws are designed to suppress the flow of information and promote uncertainty between participants (but see Jacobs 2000; Jacques and Wright 2013). The lack of contractibility limits the creditor's option in case of malfeasance, 
and there are constant temptations for transaction partners to cheat, steal, snitch, and act opportunistically (Jacques, Allen, and Wright 2014; Reuter and Caulkins 2004; see also Swedberg 1990:61). Reuter (1983:119-23) noted that creditors increase the risk premium to compensate for the added vulnerability from deferred repayment. The anticipated result is adverse selection and "moral hazard" among borrowers. It is the financially most unreliable borrowers that are willing to pay this price, and the creditor bears the burden of their risky behavior. Without formal support for the creditor in case of debtor default, we cannot expect credit under illegality to be an economically viable practice.

Both research and common knowledge reveals, however, that extending credit is a crucial part of illicit drug distribution (e.g., Adler 1993; Caulkins et al. 1999; Desroches 2005; Venkatesh 2006). Creditors deter opportunism through informal social control and the use of violence and threats (Goldstein 1985; Jacobs 2000; Jacobs and Wright 2006; Taylor 2007), but drug markets are not only regulated by threats and violence. There are many informal sanction alternatives that do not involve violence (Jacques and Allen 2013; Jacques and Wright 2008), and the decision on handling unpaid debt is always situational. A creditor may choose to reduce debts or accept losses as a cost of doing business especially if the malfeasance was unintentional (Desroches 2005; Jacques et al. 2014; Zaitch 2002). Successful distributors will generally avoid excessive violence because it is costly and attracts the attention of law enforcers (Decker and Chapman 2008; Levitt and Venkatesh 2000; Pearson and Hobbs 2003). Providing drugs on credit involves the combination of economic and social dimensions. On the one hand, it is an added cost that can be considered in the risk premium (Reuter and Kleiman 1986:303). On the other hand, it is co-offending that involves negotiation and social interaction.

Credit is a broad term for market exchange based on deferred repayment (Carruthers and Kim 2011). We use it for situations where a consignment of illicit drugs is given by a creditor to a debtor that is to be paid for upon sale. This is commonly referred to as "fronting drugs" among users and dealers (Murphy, Waldorf, and Reinarman 1990:330). In this study we focus on the peaceful, noncoercive, and cooperative aspects of credit and not on the instances wherein the debts are collected or avenged with adversarial means. Data are interviews with incarcerated drug dealers in Norway, and we explore how the contents of interpersonal ties between actors in illicit drug distribution networks above the street level affect credit provision.

This article starts by reviewing the literature that examines the economic aspects of credit and the sociology of trust in illicit drug markets. Next, we consider how the social embeddedness approach contributes to the understanding of co-offending and the inherent problems of uncertainty and vulnerability. The first part of the analysis shortly describes the widespread skepticism toward fronting in the illegal drug economy and continues to describe how the faster turnaround still makes it a favorable business model. The second part presents the relationship between trust and fronting. We 
distinguish between incidents when social relationships are a prerequisite for trust and the lessdescribed incidents when credit is used to build trust. Finally, we discuss how credit and trust interact and how they are managed in illicit drug distribution networks.

\section{The Economics of Credit under Illegality}

The drug distribution commodity chain consists of a series of stages where a principal purchases an amount of drugs that he sells in smaller amounts to a number of lower-level distributors. At each stage, the principal adds additional price per unit to compensate for risks (Malm and Bichler 2011; Reuter and Kleiman 1986). These are "batch processes" wherein the arrival of a shipment is not timed with an assessment of market demand (Caulkins and Baker 2010:220; see also Adler 1993; Morselli 2001). This demand uncertainty (Williamson 1981) complicates the distribution because it is not known what quantum the lower-level distributors are ready to buy at that given moment. This entails a serious problem of holding illicit inventory, which can be alleviated by credit because it works independently of the lower-level distributors' immediate financial situation (Venkatesh 2006). Credit enables faster distribution and reduces the inventory problem but increases other forms of uncertainty. The central problem is that repayment is contingent on the debtor's performance.

There is limited research that empirically examines the economy of credit in illegal drug markets, but a study by Caulkins et al. (1999) illustrated debtor heterogeneity. Not all debtors are equally capable of selling drugs and making a profit from it. Caulkins et al. (1999) found that among their sample ( $n$ 45) of mostly crack retail sellers, the proportion of revenue retained was related to ownership of the drugs. The most economically successful sellers were the "entrepreneurs" who paid for their drugs up front; they retained about 50 percent of the revenue. The second most successful category consisted of the "independent consignment sellers" that retained about 25 percent of revenue. Consignment sellers that sold from designated spots retained less. The least economically successful consisted of sellers paid by the hour to sell someone else's drugs.

\section{The Sociology of Trust under Illegality}

Credit poses a very specific, interpersonal trust problem in the illegal economy (Von Lampe and Johansen 2004). Trust is an elusive concept that economists will tend to avoid (Nooteboom 1996). Gambetta (1988:217) defined it as "the subjective probability that one assigns to action by another agent (or group of agents) that affects one's own action." Most of the research on credit in illicit drug markets revolves around the problem of interpersonal trust.

In a review of upper-level drug traffickers, Desroches (2007:831) noted that "friendship, kinship, and ethnicity" are variables that help create trust (see also Decker and Chapman 2008; Morselli 2001; Murji 2007; Paoli 2002; Reuter and Haaga 1989; Zaitch 2002, 2005). In a study of marijuana users and retailers, the term "friend" was used to identity reliable actors and was "enacted for the purpose of 
ensuring a stable supply of marijuana under prohibition" (Belackova and Vaccaro 2013:4). The users and retailers would only do business with friends, although the relationship could be short term and mainly for the purpose of exchanging drugs. In a study of markets for amphetamines, loyalty to a dealer was often rewarded with a better price and predict- able quality (Chalmers and Bradford 2013; see also Coomber 2003). Cultural norms have also been researched as important sources of trust in lower-level (Belackova and Vaccaro 2013; Chalmers and Bradford 2013; Sandberg 2012), mid-level (Dorn, Murji, and South 1992; Pearson and Hobbs 2003; Taylor and Potter 2013), and higher-level (Adler 1993; Dorn et al. 1992; Zaitch 2005) drug distribution.

In contrast, but consistent with this logic, Jacques et al. (2014) found that street-level retail sellers systematically rip off or defraud strangers and addicts. Interpersonal trust is most important at the higher distribution levels where the stakes are higher. Fewer sellers and buyers imply that search costs increase, the range of indeterminacy increases, interpersonal bargaining becomes more important, and the value of iterative exchanges increases (MacCoun and Reuter 1992; Preble and Casey 1969). It is unclear how this trust can be strong enough to prevent opportunistic behavior, and it remains an open question whether credit is a rational strategy for co-offenders.

We analyze the actors in our study as rational beings in the sense that they weigh the utility of alternative actions (Cornish and Clarke 2002), but note that this is a bounded rationality. Bounded rationality emphasizes the inherent limitations in making decisions under complexity and uncertainty (Williamson 1981; Wright and Decker 1994). In legal markets, creditors and debtors will attempt to act rationally and maximize their subjective expected utility (Carruthers 2013). However, co-offending situations are characterized by even more limited information and also influenced by noneconomic factors. Co-offenders will make decisions that are adequate for their ends but not necessarily optimal (Jacobs and Wright 2010). The key to making credit decisions less uncertain and more rational is to collect "private" information on transaction partner's intentions and abilities. This information complements the publicly available knowledge of credit ratings and reputations (Uzzi and Lancaster 2003:384).

\section{Credit and Trust in Drug Distribution Networks}

The economics and social dimension of credit and trust feed into each other in complex ways related to the criminal act and the organization of its completion. We propose that this integration of economic and social behaviors is best explained in a network perspective. Networks are an intermediate form between markets and hierarchies generated as a response to uncertainty that function as a mode of governance as well as a mode of coordination (Granovetter 1985; Thompson 2003). As governance, networks use trust and loyalty rather than price or rules. Trusting governance can economize on costs, promote reciprocity, reduce opportunism, and enable heuristic decision making. Reduced costs imply added value which participants are encouraged to share. Networks, therefore, require investments of 
time and money to develop and maintain low-cost governance benefits (Beckert and Wehinger 2013; Biggart and Beamish 2003; Uzzi 1997).

As coordination mode networks consist of nodes, ties, and exchanges that are studied for either their structure or their content. The research that examines drug distribution networks is focused on the implications of coordination and structure on co-offending (Malm and Bichler 2011; Morselli 2001; Tenti and Morselli 2014). Decker and Chapman (2008:151) observed that the lack of formal structure and permanence combined with the importance of culture is an advantage for drug distributers seeking protection against law enforcement. There is also some research on the higher levels of drug distribution networks that specifically include findings on credit and trust. Benson and Decker (2010) noted how smuggling networks financed shipments together and did not collect the money until the drugs were sold. Murphy et al. (1990:337) found that the decision of suppliers to front drugs was based on an evaluation of the dealers' known record for "'moving' product," his trustworthiness, and the suppliers' ability to handle an eventual loss. Desroches (2005:161) found that credit is used strategically to "attract and retain clients, expand sales and to enter new territories." He later developed this argument and suggested that credit is used as a mechanism to promote iterative exchanges and to build trust Desroches (2007). Gambetta (2009) also noted that trustworthiness is sometimes actively tested. When combined, this research found that the relative weight of the social component increased with the economic stakes involved.

\section{Transaction Costs Economics and the Social Embeddednesss Approach}

In the previous section, we observed that price and repayment schedules vary according to social relationships in the illegal drug economy. This is addressed theoretically in the network-oriented economic sociological criticisms of transaction cost economics. The baseline theory for analyzing the economics of drug distribution is "risk and prices" based on trans- action cost economics (Reuter and Kleiman 1986). The central concern in the theory is the importance of reducing "frictions," which are costs other than the price of the product (Williamson 1981:552). Transaction cost economics considers imperfect information and the value of iterative exchanges (Swedberg 1990) but struggles to explain credit under illegality. Deferred reciprocation causes frictions, which add to the price, and lead to adverse selection and moral hazard (Reuter 1983). Caulkins et al. (1999) noted that the creditor and debtor will have to meet at least twice, once to hand over the drugs and another time to deliver the money. Conversely, this also implies that participants reduce their risks by not having money and drugs present at the same time.

The issue of contention is how to assess this time spent in the company of co-offenders and contraband. Economic sociologists generally criticize transaction cost economics for reducing social relations to a "peripheral concern" and for perceiving them only as an added friction (Nooteboom 1996:986). In contrast to this, Granovetter (1985) famously proposed that economic transactions are 
"embedded" in social networks. Embedded transactions do not foreordain cooperative outcomes but merely provide a mechanism for the transfer of information. In regard to credit, this information can be used to qualify the eligibility assessment and increase informal monitoring (Carruthers 2013; Uzzi 1996; Uzzi and Lancaster 2003). The social embeddedness approach is not antithetical to transaction cost economic logic but asserts that the benefits associated with embedded transactions are not fully grasped in an economic perspective that is focused on price and frictions (Thompson 2003; Uzzi 1999).

Credit may facilitate network governance in illicit drug distribution, similar to how it expedites commerce and poses and resolves issues of trust in the legal economy (Carruthers 2005). We want to examine this further and pose the following main research question: How is credit used in illicit drug distribution? This can be further divided into two smaller research questions: What is the economics of fronting? And how is credit used in the management of interpersonal network ties?

\section{Method}

The present study is based upon interviews with 68 incarcerated drug dealers in six different prisons in southern, eastern, and western Norway. The sample was selected by approaching prisons and asking to interview incarcerated drug dealers. Both staff and fellow prisoners assisted when recruiting interviewees. Some were serving drug sentences, while others were convicted of violence. All interviewees had experience with drug distribution, from lower-level heroin dealing to large-scale, international trafficking of cocaine, amphetamine, or heroin. Most had long histories of drug abuse, particularly amphetamines or opiates (see Table 1). The interviews took place from years 2010 to 2013.

The interviewees varied a lot in their involvement in the economy. Some acted as individual entrepreneurs whereas others were connected to particular criminal groups, yet others sometimes act as individual entrepreneurs and at other times they act as if they were connected to criminal groups. It is difficult to categorize the level of involvement in illicit drug markets (Pearson and Hobbs 2003). For simplicity, we categorized sample members according to guidelines from the Norwegian Director General of Public Prosecution, which demarcate three levels of severity in the penal code (see Table 2).

Interviews lasted from 1.5 to 2.5 hours and were carried out by a team of five researchers with previous experience in qualitative interviewing with hard-to- reach populations. We followed a general interview guide developed in advance, but interviewers were free to follow-up on themes that emerged in the course of the interviews. Interviews were recorded, transcribed, and coded in the qualitative data processing program Hyper Research.

When the interviews were analyzed, several key themes were coded broadly. The codes were established according to predefined research interests, one of which was drug dealing. This category had several sub-categories including (i) credit, (ii) sales, (iii) purchases, (iv) conflict resolution, (v) relations upward in the dealing hierarchy, (vi) relations downward in the dealing hierarchy, and (vii) 
organization of work. The credit code included all incidents of the use of credit in the data and was the starting point for the analysis in this study. We coded it further and more analytically, identifying important themes when dealers talked about fronting: (i) skepticism toward fronting, (ii) faster turnaround, (iii) trust as a prerequisite to credit, and (iv) how credit builds trust. This now makes up the main parts of the analysis. These codes emerged from the process of data collection and interpretation. Both authors coded these analytical themes to secure interrater reliability. We use trust as a sensitizing concept (Blumer 1954) to see, organize, and understand experience, and we made no attempt to operationalize it in this study.

The analysis in this study can be criticized for being "instrumentalist" (Carruthers 2005:366), and symbolic interactionists observe that actors will work to "appear rational, reasonable, and accountable" (Biggart and Beam- ish 2003:456). This may have been fortified by the prison setting where the interviews took place (Wright and Decker 1994). It can also be argued that the imprisoned population represent a selective group of unsuccessful drug dealers. Prison interviews, however, also have advantages. They allow access to a hidden population, and participants are likely to be motivated, contemplative, and clear-headed (Copes and Hochstetler 2010). Qualitative interviews can only claim moderate representativeness, but our theme builds on previous work on peace in drug markets (Jacques and Wright 2008) and also contributes to the study on how network ties are maintained and why they matter (Beckert and Wehinger 2013; Uzzi 1999).

Table 1. Sample characteristics (gender, age, type of drug distributed, hierarchical classification, primary drug use)

\begin{tabular}{|l|l|l|}
\hline & $\mathrm{N}=68$ & Percentage \\
\hline Gender & 40 & $59 \%$ \\
\hline Male & 28 & $41 \%$ \\
\hline Female & & \\
\hline Age & 20 years & \\
\hline Minimum & 50 years & \\
\hline Maximum & 35 years & \\
\hline Mean & \\
\hline
\end{tabular}




\begin{tabular}{|c|c|c|}
\hline \multicolumn{3}{|c|}{ Type of drug distributed } \\
\hline Amphetamines & 26 & $38 \%$ \\
\hline Cannabis & 18 & $27 \%$ \\
\hline Heroin & 14 & $21 \%$ \\
\hline Cocaine & 5 & $7 \%$ \\
\hline Ecstasy & 2 & $3 \%$ \\
\hline Other & 3 & $4 \%$ \\
\hline \multicolumn{3}{|c|}{ Hierarchical classification } \\
\hline Low & 8 & $12 \%$ \\
\hline Middle & 45 & $66 \%$ \\
\hline High & 15 & $22 \%$ \\
\hline \multicolumn{3}{|c|}{ Primary drug use } \\
\hline Amphetamine & 37 & $54 \%$ \\
\hline Opiate & 16 & $23 \%$ \\
\hline Cannabis & 11 & $16 \%$ \\
\hline Cocaine & 3 & $4 \%$ \\
\hline Other & 2 & $3 \%$ \\
\hline
\end{tabular}

Table 2. Hierarchical ordering of drug economy actors based on guidelines from the Norwegian Director General of Public Prosecution according to the triple-tier in the Penal Code Section 162

\begin{tabular}{|l|l|l|l|}
\hline Substance & Lower-Level & Mid-Level & High-Level \\
\hline Heroin & $<15$ grams & $\geq 15$ grams & $\geq 750$ grams \\
\hline
\end{tabular}




\begin{tabular}{|l||l|l|l|}
\hline Cocaine & $<50$ grams & $\geq 50$ grams & $\geq 3$ kilos \\
\hline Amphetamine & $<50$ grams & $\geq 50$ grams & $\geq 3$ kilos \\
\hline Cannabis & $<1$ kilo & $\geq 1$ kilo & $\geq 80$ kilos \\
\hline Ecstasy & $<350$ tablets & $\geq 350$ tablets & $\geq 15,000$ tablets \\
\hline
\end{tabular}

\section{Economics of Fronting}

Here we focus on the aspects of credit that are primarily economic in nature. We first examine the problems that follow from the increased risk premium and how it affects creditor's vulnerability as well as debtor's concern for being unable to repay. Next, we examine the economic advantages of faster distribution and the associated benefits for maintaining good interpersonal relations.

\section{Skepticism toward Fronting}

An important sentiment among the drug dealers was skepticism for owing money. This was the case for dealers who did not want to become creditors as well as dealers who would rather not be debtors. Many interviewees expressed their preference to avoid credit. A male mid-level cannabis dealer stated:

"I only buy from people I know, but no one decides over what I buy, right. I would never want that either, I don't like it at all. So I use my own money to buy drugs, money that I may have earned from other crimes, right, which in turn finances the ... I'd never get fronted from anyone."

Being your own boss and in charge of your business is important. Avoiding credit is also a way to avoid trouble. One female mid-level amphetamines dealer argued, "That's how you get away with it, all those tricky situations, if you don't front. Giving credit doesn't pay." Owing money to drug dealers involved a lot of stress from the fear of getting arrested. A male high-level heroin dealer explained:

“A lot of people get fronted drugs and everything goes haywire once they're caught, they'll owe money, and one thing leads to another, like snitching. I've started out with a sum of money in order to buy just a little, and I sell that. So I've been careful at the very beginning, built it up, and after a while things start running on their own."

Much of the skepticism followed from the higher price of fronted drugs. A male lower-level cannabis dealer described the price difference as 8,000 Norwegian kroner (NOK) for 100 grams when the drug was given on credit as opposed to 7,000 when it was paid for cash. Cash payment is perceived by many as a step upward in terms of income and business. One female mid- level cocaine dealer stated, "Once 
you've built yourself up in such a way that you can start paying for whatever you buy, that's when you start mak- ing money, right." A male high-level cannabis dealer similarly said, "No, right, we'd get drugs fronted to start off with, but you make more money when you pay the full price upfront."

A female mid-level amphetamines dealer first denied fronting with reference to the vulnerability associated with potential default but then admitted to it occasionally, with some restrictions:

“T: They won't get the goods off me if I don't see cash up front.

I: They're unable to purchase drugs on credit from you?

T: They'd have to be people I trust one hundred percent. But they can never get fronted more than they receive off their welfare checks or more than I know they can pay back."

By not fronting more than she knew, debtors would be able to pay back; she reduced her risk of losing the money (Murphy et al. 1990). Other sellers explained similar strategies for reducing vulnerability. One male mid- level amphetamines dealer provided a detailed description of how he operated:

“OK, let's say I owe 50,000; and I can make 90,000 or 100,000-I'll make sure that I keep enough drugs on hand to cover the 50,000-if whatever I sell suddenly goes to hell (...) To start with I have to make sure that I only accept cash payments, I won't even give it to people I trust before I've built up my buffer. When I've built up a secure buffer, that's when I can start gambling a little."

A mid-level cannabis dealer said, "Whenever I've lent anything, I'd never front without having the security to back those loans up by myself. So people who borrowed from me, they never had any payback time pressure on them, right." A high-level amphetamines dealer stated, "You shouldn't front stuff that you've been fronted, things like that. If you only stick to those rules you'll never owe money either." This was mentioned by most of our interviewees as an informal "rule" of the illegal drug economy (see also Desroches 2005). The higher price and associated problems with potential debtor default are important reasons to avoid credit.

Even among the most skeptical, however, the practice was common. Sometimes because they were desperate about getting drugs or money, other times because they were presented with a particularly tempting offer. A male mid-level amphetamines seller stated that "nearly ten out of ten regulars will buy fronted drugs." He continued:

"Almost nobody pays cash. Those who pay cash are not regulars. They're the ones who are from out of town. You don't give a shit about them. You don't need to build up any kind of relationship with them." 
A male mid-level dealer noted how cash sales were difficult: "The ones that try to sell drugs in exchange for cash, they just never last. No matter how good their stuff is, it rarely works. At least not with heroin." Cash sales are difficult, because customers may expect fronting, and insisting on cash may send the signal that the seller is an outsider to the local drug economy (Jacques, Allen, and Wright 2014).

According to economic theory, the higher price for credit may cause adverse selection and moral hazard among debtors. Those that are willing to accept the increased price are also more likely to default on repayment (Reuter 1983). These problems are exemplified by the drug users in this study who used credit when they are "desperate" for drugs or money. In contrast to these borrowers, we found that most of our interviewees were aware of having sensible economic practices. They waited until they had an economic buffer so that they did not become insolvent, but acknowl- edged that situational factors like tempting offers could make them compro- mise this principle. This cautiousness may be attributable to the way in which they were found to be eligible in the first place. Our interviewees described the eligibility decision as embedded in social relationships. This entails that the creditor can gain access to information on debtor's personal finances as well as more subtle signals of social proximity (Carruthers and Kim 2011; Jacques et al. 2014; Uzzi and Lancaster 2003). These interpersonal ties and the informal monitoring that follow alleviate the economic problems, but the creditor is still vulnerable to defaults. This added vulnerability may be partially off set by other economic advantages.

\section{Faster Turnaround}

Although dealers were skeptical of the increased prices, the added uncertainty did not prevent credits, as it had many advantages. One female mid-level heroin dealer said, "Yes, we fronted to everyone. And people settled their debts." Others noted that there were actually several economic advantages associated with fronting. A male high-level amphetamines dealer stated that it was necessary for him to sell on credit to make enough money. He made it work by letting people in his network know in advance that he had drugs coming in "to prepare them." Another male high-level amphetamines dealer further elaborated:

“I: If you've got 20 kilos of amphetamines, how would you go about getting rid of the stuff? Would you front it?

R: In order to make money, you have to front. But then you need to have peo- ple around and be prepared to stick to your guns, right. Because when I was sitting on those loads I had to sell at a low price, right. I wouldn't make more than 60-65 thousand [per kilo], cash. But if I fronted I could get about $80-85$, up to 90 . So it makes a difference. And that's not a long time period of credit, we're talking one week. 


\section{I: One week?}

R: Yeah, yeah, forget about it, with amphetamines the stuff moves so quick that it's no problem. I chose to settle for a level where I wouldn't get any stress. I was in touch with people that I trusted one hundred percent and that I knew were alright."

This points toward an important qualification to the question of increased credit price. The added friction from deferred reciprocation has to be seen in comparison to the costs of sitting on illicit inventory (Caulkins and Baker 2010). A male mid-level amphetamines dealer explained: "I go by quantity, large amounts, right, how fast it goes. That's why I'd rather accept a couple of losses in order to get the right (dealers). I'll get rid of the ones that aren't good enough." The advantages of faster distribution are more important to this dealer than the uncertainties associated with the deferred repayment. Defaults were used as information on debtor heterogeneity, making creditor's assessment of "subjective probability" more rational (Carruthers 2013; Gambetta 1988).

When we inquired into how this affected earnings, a male mid-level amphetamines dealer answered:

"I always calculate a 30 percent margin of loss. On everything. Between 20 and 30 percent is what I've calculated are my losses on average. So if I sell one kilo, around 20 to 30 percent is going to be a loss, gone. That's a lot. That's why you need to charge higher prices."

These quotes illustrate how fronting affects the problems of inventory costs and information asymmetry. It reduces the cost of holding inventory, because distributors do not have to wait until buyers have available funds. Creditors in this study used their network to get the product to the market quickly (Adler 1993; Venkatesh 2006), similar to how networks function in legal markets (Uzzi 1997). This expediency increases the problem of debtor defaults, but these losses are not only negative. Debtors that fail to repay constitute points of information and are excluded from future business, which improves network coordination and efficiency over time. This is a continuous process of selection based on evaluating performance and retaining the good debtors (Desroches 2005, 2007; Gambetta 2009; Murphy et al. 1990). Deferred reciprocation increases uncertainty and vulnerability and also facilitates faster distribution, reduces storage costs, and provides information.

\section{Trust and Fronting}

Here we examine two aspects of fronting that regard governance through trusting social relationships. Credit poses and resolves issues of trust and reputation that are constantly evaluated. We examine the various foundations of trust and the processes by which it is managed. 


\section{Social Relationships as a Prerequisite for Trust}

There are different ways of earning the trust necessary to be eligible for credit. A male mid-level cannabis dealer emphasized the importance of reputation:

"E: Not everyone can just walk up and borrow 300,000 either, right, but you are who you are, you've done the things you've done, you've got nothing left to prove, right. So when you're broke, like when I got out after three years, or two-and-a-half years, then you've got buddies you've helped out earlier, so then they get to help out when I get out right, right, that's com- mon sense.

\section{I: So that sort of trust is quite important?}

E: It means everything, everything hinges on whether you've got a good name, whether you've got a good reputation. So it makes a huge difference."

His record of having helped others on prior occasions provided him with a reputation for trustworthiness. His "good name" is a result of an extended engagement in the illegal economy. One female mid-level amphetamine dealer described her strategy as follows: "I live by the philosophy that if you sell the drugs cheap and clean, then payment won't be a problem." By being a "decent" dealer, she motivated people to pay their debt (Belackova and Vaccaro 2013; Chalmers and Bradford 2013). A mid-level amphetamines dealer explains how prison helped his status:

"When I got out, a couple of days passed, and then people would come and ring my doorbell, even strangers, the Hells Angels, they'd all come and ask how much I needed. Fronting a couple of kilos here and there. It was like, wow. I hadn't run my mouth and they all knew. I was relatively new in town and people didn't know what I was like, but after I got out they knew who I was. In a way, it was like I'd passed my exams. The police built me a nice resume'."

It is not the prison sentence in itself but rather the demonstrated ability to act loyally under pressure that secured our interviewees' legitimacy with the Hells Angels. Another example comes from a female mid-level amphetamines dealer who got tablets on credit from a former boyfriend. Friendships could also be a good start for a credit. By having pre-established relationships, one can compensate for some of the uncertainty in the illegal market. One high-level male amphetamines dealer explained:

"Right, a regular guy off the street can't just walk up to you and buy 20 kilos. It doesn't work like that. The way it works is you've got to build it up, right. Or that someone can vouch for you. Childhood friends, people you grew up with, or you know them but you've never done business together, right. And then you can come in one day and say, damn, now I want to get my hands dirty and get involved in the business. "Yeah, sure you get on board, I know you from way back when, you're a good guy," that sort of thing. That's how you build it up." 
Another male mid-level amphetamine dealer spoke about starting out in the business by receiving 100 grams of resin for such a low price that the seller did not make any money. The creditor had known his father to be a trustworthy dealer and wanted to facilitate getting the son started in the business. The initial favorable credit was an investment on behalf of the creditor, an attempt to recruit a new participant to his network. A male mid-level heroin dealer described the process of discerning who to trust as "social anthropology" based on previous relationships but also on people skills: "We all rely on honesty and faith," echoing Uzzi’s (1997) observation of heuristic decision making in networks.

Credit is based on a promise to repay and poses a specific problem of interpersonal trust. The literature on illicit drug distribution found that friendship and kinship can help resolve this (e.g., Reuter and Haaga 1989; Von Lampe and Johansen 2004), and our interviews coincide with this. However, we also noted two qualifications that need to be included in the understanding of interpersonal trust in the context of networks. First, it is interesting that the trust between the creditor and the father was extended to a third party, in this case, the son. Uzzi (1996) found a similar transmission of trust in legal networks. This illustrates that the interpersonal trust built through successful reciprocations also becomes a network resource that can be invested in attracting new partners. Second, our interviewees explained how they continuously evaluated and invested in their relationships and individual reputations. This is most concisely illustrated by the dealer that fronted drugs at a low price as a way to encourage reciprocity (Desroches 2005). Low price is an economic incentive, but seen in the context of network governance, it also has other implications. Trusting relations reduce frictions but network governance also entails that partici- pants are encouraged to share the added value that follows (Uzzi 1999). This dealer strengthened the interpersonal ties that allowed her to use credit in the first place. A low credit price can be a benefit to both parties, because it provides incentive, reduces frictions, and creates added value in the longer run.

\section{Using Credit to Build Trust}

Social relationships are a source of trust, but those will not suffice when moving further up the distribution ladder. Participation at this level requires a record of reliability that is proven over time. Credit may contribute to this and help resolve trust issues, because credit is also an investment in network governance and longer-term cooperation. One male mid-level amphetamines dealer explained that to get a hectogram, you have to "earn it." When we asked how that was done he replied:

"Usually, the way it works is you start small. Usually you've small-time deal- ers working for you and who are good at what they do in their own way. And then they get a little more. They do better as time goes, you give them 20 grams. They build up your trust. That's how I made it at least. After a while in this game, you see people acting reliable for a while, but 99 out of a 100 people will mess up sooner or later." 
This creditor mediated his vulnerability by assessing performance through a series of reciprocations (Desroches 2007; Uzzi 1999). He learned and actively engaged in forming actions by investing money, drugs, and time in the interpersonal relationships. One male mid-level amphetamines dealer explained his relationship with his creditors in this way:

"I'll be thinking, OK, he fronts me this stuff, that's his style, he trusts me, he shows me trust, he spends his own money buying something that he passes on to me. He's taking a risk. So that way I'll be thinking, I better show him that I can make good, sure thing. That's your sense of security, right there, and right away you've got a very different relationship than between a buyer and a seller. You get a kind of friendly relationship going, in a way, like, business is business, but seeing as how he's giving me this chance, I won't let him down. And that's when you take it to a completely different level, and when the cops catch you, you're thinking, I'm not going to let him down."

A male high-level amphetamines dealer explained how the same mechanisms worked downward in the hierarchies, toward his debtors:

“The minute you show a guy who's selling drugs a little trust, he'll do his best, right. If you say to him, 'OK, here you go, go work a little, and enjoy yourself, we'll talk in 10 days' time' or something like that, you'll get this, 'Ah!' They get this feeling that, 'He's showing me trust.' But if you tell them, like, 'You'll pay me 30 today and 35 in a week,' then they'll get stressed out, they'll get stressed, 'Oh shit, fuck, motherfucker.' It's weird but that's just how it works."

In many of our interviews, drug distribution is described in labor market terms (see also Dwyer and Moore 2010). One distributor equated his first meetings with potential lower-level dealers as a job interview. A male mid-level amphetamines dealer was very explicit in using an employer- employee analogy:

"The important part is that you give them compliments for whatever they're doing, just like a boss would in a regular business, that you're doing a good job, right. You need to give people raises, you need to praise them. Something to make them feel more engaged, to make them like their employer. And the more you build on that, the better the relationship gets, right. That's why the highest link in the chain never gets caught. Because there's two or three others below him that have so much trust, they like the person so much that they'd rather do prison time."

The potential for arrest is a source of constant vulnerability and uncertainty. All countries have ways of offering arrestees reduced sentences in return for information on criminal networks. Snitching might be the most rational option when weighed against severe criminal sanctions, but our interviewees offered many examples of debtors that declined this opportunity for defection. Some 
dealers offered economic incentive to stay loyal by canceling debts for arrested partners. One female high-level amphetamines dealer explained:

"Well, things have to be that way. If they were to get out and still owe several hundred thousand, they'd lost the drugs and they've gone to prison-in a way they're getting paid to keep their mouths shut. Because I was sitting there making money off what they were doing."

Creditors differed on this question. A male mid-level cannabis dealer stated that he would never take credit "because you run the risk of having to pay down your debts after doing time in prison, right, and I'm not interested in that." Similarly, the smugglers interviewed by Decker and Chapman (2008) were responsible for the drugs they lost. This assessment will always be situational and related to the history of cooperation and reciprocations between the two. A history of doing business and sharing private information will reduce opportunism, but it remains an open question how much this affects loyalty confronted with severe criminal sanctions. A male high-level amphetamines dealer concluded as follows: "When things go to hell, it's nice having people on good terms with you." Trusting network governance negates opportunism. The more successful reciprocations, the stronger the interpersonal trust. In this way, credit helps resolve trust issues by providing a mechanism in the network that is used to demonstrate and test trustworthiness.

\section{Discussion and Conclusion}

In this study, we have presented the economic disadvantage and advantages of fronting drugs, and the way in which this process poses and resolves problems of trust. We examined the central economic problem of how the higher credit price may cause problems in selecting irresponsible borrowers who fail to repay (Reuter 1983). The drug dealers described their skepticism toward credit in ways that coincided with these problems, but this alone does not capture the complexity and contingency of credit under illegality. We found that problems associated with higher credit price were overcome by embedding transactions in social relations. The creditors and debtors in our study explained that they do not meet twice, first to hand over the drugs and then to hand over the money (Caulkins et al. 1999), but rather, a number of times. These ongoing social relationships improve informal monitoring of sales and provide subtle signals on trustworthiness (Carruthers 2013; Uzzi 1999; Uzzi and Lancaster 2003). The socially negotiated nature puts emphasis on the social trust component (Beckert and Wehinger 2013) and a too narrow focus on the problems of moral hazard and adverse selection constitutes an under-socialized (Granovetter 1985) understanding of credit under illegality.

This is not to say that the increased risk premium and vulnerability associated with debtor default is inconsequential. All of our interviewees were acutely aware of the problems that follow from arrests and inability to repay. Generally, debtors preferred to have a financial buffer and to let credit be contingent on career trajectory. In the early stages of a drug distribution career, credit can be 
necessary to get started without having the economic means available. Our study provides examples of how initial consignments of drugs were provided with the expressed intention of starting someone in the drug distribution business. Later in a career, credit is also a necessary part of drug distribution but for other reasons. Here, the debtor must signal social proximity and willingness to engage in a reciprocation process that entails several meetings, otherwise he may fall into the cate-gory of the stranger (Carruthers 2005; Jacques et al. 2014; Uzzi 1997). Motives for giving and taking credit vary with career trajectory, and the weight of the social component increases in importance relative to the amounts traded (MacCoun and Reuter 1992; Preble and Casey 1969). Social contact reduces uncertainty and compensates for the economic disadvantages that follow from increased price and deferred reciprocation.

Fronting drugs also has economic advantages because it expedites commerce and reduces inventory costs. Drug dealers in this study described how they prepared their network partners prior to the arrival of a shipment (Caulkins and Baker 2010; Desroches 2007; Zaitch 2002). Yet, sometimes, the inventory problem persisted and dealers would eventually lower prices and relax repayment schedules to further entice transaction partners. This price reduction strategy illustrates the central importance of inventory costs and search costs in the higher levels of drug distribution. After a while, it may be preferable to sell at a lower price in order to stop accumulating these costs.

Prioritizing fast distribution has other costs. Expediency will likely be followed by a higher proportion of defaults than credits based on more careful assessments. Our interviewees explained that such losses are tolerable due to the information on debtor performance that was derived from them. This logic extended to situations wherein the creditor proactively chose to front drugs to someone on a weak foundation of information and trust. The idea was to use a consignment as an investment in testing if there is a basis for future trusting relations (Gambetta 2009). This strategy of acquiring information at a cost is used to make decisions on selecting partners. Debtors that do not act according to the interest of the creditor and take too many risks may be successful but will still be deemed as morally hazardous and written off in favor of more cautious partners (Desroches 2005, 2007; Murphy et al. 1990).

The continuous cycle of evaluating compliance, risk aversion, and results among debtors can be termed as cooperative selection. Cooperative selection is understood in contrast to the adverse selection predicted by economic theory wherein the higher credit price entails that only the poorest segment of borrowers will accept credit (Reuter 1983). Cooperative selection conversely entails that good debtors are retained, and poor performance leads to expulsion from the network. This is achieved on the basis of acquired information about the debtor's economic situation as well as softer knowledge on compliance and risk aversion in the course of reciprocating the credit (Desroches 2005, 
2007; Murphy et al. 1990). The network is a priming mechanism for information transfer (Uzzi and Lancaster 2003), and credit is a priming mechanism for information acquired at a cost.

Credit can therefore be understood as a form of network capital that is strategically used to maintain interpersonal relations, evaluate debtor performance, promote loyalty, and improve insulation against law enforcement intervention. Several drug dealers in this study calculated their margin of loss from a 20 to 30 percent probability. This echoes the economic notion of risks and probabilities, whereas the social embeddedness approach perceives such assessments under uncertainty as inherently incalculable. Conceptually, we can say further information can move the decision from uncertainty toward probability but never achieve it (Carruthers 2013; Nooteboom 1996). The contradiction of attempting to act rationally in an inherently uncertain context is contained in Gambetta's (1988) definition of trust as based on "subjective probability." This perspective on co-offending con- forms well the notion of bounded rationality. All participants in drug distribution recognize that unforeseen events can and will occur, but they still attempt to make situational assessments as rational as possible (Carruthers 2013).

This does not undermine the assumption of bounded rationality but rather strengthens the point that information is acquired at a cost. What may appear from an objective observer's point of view as a weak foundation for trust may in fact be an example of testing of trust, risking trust under adverse conditions, or other functional alternatives to actual trust (Gambetta 2009; Von Lampe and Johansen 2004; Zaitch 2002). Credit under illegality is a good example of bounded rationality. Drug dealers are not seeking to maximize or act opportunistically in each transaction, rather, the decision on price and repayment schedule is situational (Taylor 2007) but understood in the context of a series of exchanges. Decision making here is affected by noneconomic factors (Jacobs and Wright 2010), and our interviewees also admitted that desperation sometimes takes over.

References in interviews to labor market relations illustrate this well, particularly in relation to debtor defaults following arrests. The decision on how to respond after an arrest is not only a prisoner's dilemma in regard to sentence severity versus the eventual consequences of being disciplined. There is a sense of loyalty toward the higher-level distributor that is explained as a form of repayment of prior trust and economic investments. Debtors in this study related stories about how credit makes them feel trusted and appreciated, and that this makes them act loyally when arrested. In some cases, debtors were ultimately paid not to snitch. Credit provision is a central component in establishing and maintaining loyalty. This is an important aspect of how illicit drug distribution can survive the external shocks from law enforcement intervention (Decker and Chapman 2008). The strength of the interpersonal ties wherein trust becomes loyalty help explain how networks do not succumb to retaliatory violence over defaulted debts and arrests but rather manage to resolve disputes in a cooperative manner. 
Summing up, we have found that credit integrates the economic and social dimensions of drug distribution, because it ties together the resource exchange and the informal social control aspects. It is also an invaluable part of the information transfer that alleviates the uncertainty of operating under illegality. Interpersonal network ties are used to transmit information on intentions and ability. Investing time and other resources in strengthening these ties is a rational way to reduce the vulnerability and search costs associated with finding new partners at the higher levels of illicit drug distribution. Credit becomes part of the distribution network's collective resources, and it is important for both coordinating and governing networks and invaluable for expediting the distribution process and avoiding inventory. Credit is contingent upon investments of time, money, and drugs, but improves network effectiveness. Similar to the legal economy, credit in illicit drug distribution simultaneously poses and resolves issues of trust, stimulates and eases commerce, and reduces the need for formal control and close monitoring of transaction partners.

\section{References}

Adler, Patricia A. 1993. Wheeling and Dealing: An Ethnography of an Upper-level Drug Dealing and Smuggling Community. New York: Columbia University Press.

Beckert, Jens and Frank Wehinger. 2013. "In the Shadow: Illegal Markets and Economic Sociology." Socio-economic Review 11:5-30.

Belackova, Vendula and Christian Alexander Vaccaro. 2013. “'A Friend with Weed Is a Friend Indeed': Understanding the Relationship between Friendship Identity and Market Relations among Marijuana Users." Journal of Drug Issues 43: 289-313.

Benson, Jana S. and Scott H. Decker. 2010. "The Organizational Structure of Inter- national Drug Smuggling." Journal of Criminal Justice 38:130-38.

Biggart, Nicole W. and Thomas D. Beamish. 2003. "The Economic Sociology of Conventions: Habit, Custom, Practice, and Routine in Market Order." Annual Review of Sociology 29:443-64.

Blumer, Herbert. 1954. “What Is Wrong with Social Theory?” American Sociological Review 18:3-10. Carruthers, Bruce G. 2005. “The Sociology of Money and Credit.” Pp. 355-78 in The Handbook of Economic Sociology, 2nd ed., edited by N. J. Smelser and R. Swedberg. Princeton, NJ: Princeton University Press.

Carruthers, Bruce G. 2013. "From Uncertainty towards Risk: The Case of Credit Ratings." Socio-economic Review 11:525-51. 
Carruthers, Bruce G. and Jeong-Chul Kim. 2011. “The Sociology of Finance." Annual Review of Sociology 37:239-59.

Caulkins, Jonathan P. and David Baker. 2010. "Cobweb Dynamics and Price Dispersion in Illicit Drug Markets." Socio-economic Planning Sciences 44: 220-30.

Caulkins, Jonathan P., Bruce Johnson, Angela Taylor, and Lowell Taylor. 1999. "What Drug Dealers Tell Us about Their Costs of Doing Business." Journal of Drug Issues 29:323-40.

Chalmers, Jenny and Deborah Bradford. 2013. "Methamphetamine Users' Perceptions of Exchanging Drugs for Money: Does Trust Matter?" Journal of Drug Issues 43:256-69.

Coomber, Ross. 2003. “There's No Such Thing as a Free Lunch: How 'Freebies' and 'Credit' Operate as Part of Rational Drug Market Activity." Journal of Drug Issues 33:939-62.

Copes, Heith and Andy Hochstetler. 2010. "Interviewing the Incarcerated: Pitfalls and Promises." Pp. 49-67 in Offenders on Offending: Learning about Crime from Criminals, edited by W. Bernasco. Oxford, UK: Routledge.

Cornish, Derek and Ronald Clarke. 2002. "Analyzing Organized Crime." Pp. 41-63 in Rational Choice and Criminal Behavior: Recent Research and Future Chal- lenges, Vol. 32, edited by A. R. Piquero and Stephen G. Tibbetts. Oxford, UK: Psychology Press.

Decker, Scott H. and Margaret Townsend Chapman. 2008. Drug Smugglers on Drug Smuggling. Philadelphia, PA: Temple University Press.

Desroches, Frederick. 2005. The Crime That Pays. Drug Trafficking and Organised Crime in Canada. Toronto: Canadian Scholar's Press Inc.

Desroches, Frederick. 2007. “Research on Upper Level Drug Trafficking: A Review." Journal of Drug Issues 37:827-44.

Dorn, Nicholas, Karim Murji, and Nigel South. 1992. Traffickers: Drug Markets and Law Enforcement. Oxford, UK: Psychology Press.

Dwyer, Robyn and David Moore. 2010. "Beyond Neoclassical Economics: Social Process, Agency and the Maintenance of Order in an Australian Illicit Drug Mar- ketplace." International Journal of Drug Policy 21:390-98.

Gambetta, Diego. 1988. “Can We Trust.” Pp. 213-37 in Trust: Making and Break-ing Cooperative Relations, edited by D. Gambetta. Oxford, UK: Blackwell. 
Gambetta, Diego. 2009. Codes of the Underworld. Princeton, NJ: Princeton Univer- sity Press.

Goldstein, Paul J. 1985. “The Drugs/Violence Nexus.”Journal of Drug Issues 15: 493-506.

Granovetter, Mark. 1985. "Economic Action and Social Structure: The Problem of Embeddedness." American Journal of Sociology 91:481-510.

Jacobs, Bruce A. 2000. Robbing Drug Dealers: Violence beyond the Law. Living- ston, NJ: Transaction Publishers.

Jacobs, Bruce A. and Richard Wright. 2006. Street Justice: Retaliation in the Crim-inal Underworld. Cambridge, MA: Cambridge University Press.

Jacobs, Bruce A. and Richard Wright. 2010. "Bounded Rationality, Retaliation, and the Spread of Urban Violence.” Journal of Interpersonal Violence 25:1739-66.

Jacques, Scott and Andrea Allen. 2013. "Bentham's Sanction Typology and Restrictive Deterrence: A Study of Young, Suburban, Middle-class Drug Dealers." Journal of Drug Issues 44:212-30.

Jacques, Scott, Andrea Allen, and Richard Wright. 2014. "Drug Dealers' Rational Choices on Which Customers to Rip-off." International Journal of Drug Policy 25:251-56.

Jacques, Scott and Richard Wright. 2008. “The Relevance of Peace to Studies of Drug Market Violence." Criminology 46:221-54.

Jacques, Scott and Richard Wright. 2013. "How Victimized Drug Traders Mobilize Police." Journal of Contemporary Ethnography 42:545-75.

Levitt, Steven D. and Sudhir A. Venkatesh. 2000. “An Economic Analysis of a Drug-selling Gang's Finances." The Quarterly Journal of Economics 115:755-89.

MacCoun, Robert and Peter Reuter. 1992. “Are the Wages of Sin $\$ 30$ an Hour? Eco- nomic Aspects of Street-level Drug Dealing." Crime \& Delinquency 38:477-91.

Malm, Aili and Gisela Bichler. 2011. "Networks of Collaborating Criminals: Asses- sing the Structural Vulnerability of Drug Markets." Journal of Research in Crime and Delinquency 48:271-97.

Morselli, Carlo. 2001. "Structuring Mr. Nice: Entrepreneurial Opportunities and Brokerage Positioning in the Cannabis Trade." Crime, Law and Social Change 35:203-44.

Murji, Karim. 2007. "Hierarchies, Markets and Networks: Ethnicity/Race and Drug Distribution." Journal of Drug Issues 37:781-804. 
Murphy, Sheigla, Dan Waldorf, and Craig Reinarman. 1990. "Drifting into Dealing: Becoming a Cocaine Seller." Qualitative Sociology 13:321-43.

Nooteboom, Bart. 1996. “Trust, Opportunism, and Governance: A Process and Control Model." Organization Studies 17:985-1010.

Paoli, Letizia. 2002. “The Paradoxes of Organized Crime." Crime, Law and Social Change 37:51-97.

Pearson, Geoffrey and Dick Hobbs. 2003. "King Pin? A Case Study of a Middle Market Drug Broker." The Howard Journal of Criminal Justice 42:335-47.

Preble, Edward and John J. Casey. 1969. "Taking Care of Business: The Heroin User's Life on the Street." Substance Use \& Misuse 4:1-24.

Reuter, Peter. 1983. Disorganized Crime: The Economics of the Visible Hand. Cambridge, MA: MIT Press.

Reuter, Peter and Jonathan P. Caulkins. 2004. "Illegal 'Lemons': Price Dispersion in Cocaine and Heroin Markets." Bulletin on Narcotics 56:141-65.

Reuter, Peter and John Haaga. 1989. “The Organization of High-level Drug Markets.” Retrieved November 7, 2013 (http://www.rand.org/cgi-bin/ Abstracts/e-getabbydoc.pl?doc $1 / 4$ N-2830).

Reuter, Peter and Mark Kleiman. 1986. "Risks and Prices: An Economic Analysis of Drug Enforcement." Crime and Justice 7:289-340.

Sandberg, Sveinung. 2012. "The Importance of Culture for Cannabis Markets: Towards an Economic Sociology of Illegal Drug Markets." British Journal of Criminology 52:1133-1151.

Swedberg, Richard. 1990. Economics and Sociology: Redefining Their Boundaries- Conversations with Economists and Sociologists. Princeton, NJ: Princeton University Press.

Taylor, Angela P. 2007. How Drug Dealers Settle Disputes: Violent and Nonviolent Outcomes. Monsey, NY: Criminal Justice Press.

Taylor, Matthew and Gary R. Potter. 2013. “From 'Social Supply' to 'Real Dealing': Drift, Friendship, and Trust in Drug Dealing Careers." Journal of Drug Issues 43:392-406.

Tenti, Valentina and Carlos Morselli. 2014. "Group Co-offending Networks in Italy's Illegal Drug Trade." Crime, Law, and Social Change 62:21-44.

Thompson, Grahame F. 2003. Between Hierarchies and Markets: The Logic and Limits of Network Organization. Oxford, UK: Oxford University Press. 
Uzzi, Brian. 1996. “The Sources and Consequences of Embeddedness for the Economic Performance of Organizations: The Network Effect." American Sociological Review 61:674-98.

Uzzi, Brian. 1997. "Social Structure and Competition in Interfirm Networks: The Paradox of Embeddedness." Administrative Science Quarterly 42:35-67.

Uzzi, Brian. 1999. "Embeddedness in the Making of Financial Capital: How Social Relations and Networks Benefit Firms Seeking Finance." American Sociologi-cal Review 64:481-505.

Uzzi, Brian and Ryon Lancaster. 2003. "Relational Embeddedness and Learning: The Case of Bank Loan Managers and their Clients." Management Science 49:383-99.

Venkatesh, Sudhir A. 2006. Off the Books. Cambridge, MA: Harvard University Press.

Von Lampe, Klaus and Per Ole Johansen. 2004. "Organized Crime and Trust: On the Conceptualization and Empirical Relevance of Trust in the Context of Criminal Networks." Global Crime 6:159-84.

Williamson, Oliver E. 1981. "The Economics of Organization: The Transaction Cost Approach." American Journal of Sociology 87:548-77.

Wright, Richard T. and Scott Decker. 1994. Burglars on the Job. Boston, MA: Northeastern University Press.

Zaitch, Damia'n. 2002. "From Cali to Rotterdam: Perceptions of Colombian Cocaine Traffickers on the Dutch Port." Crime, Law and Social Change 38:239-66.

Zaitch, Damia'n. 2005. "The Ambiguity of Violence, Secrecy, and Trust among Colombian Drug Entrepreneurs." Journal of Drug Issues 35:201-28.

\section{Author Biographies}

Kim Moeller is Associate Professor of Criminology at the Department of Sociology and Social Work at Aalborg University. His research is focused on drug markets, policing, drug control policy and organized crime.

Sveinung Sandberg is Professor of Criminology in the Department of Criminology and Sociology of Law at the University of Oslo. His research focuses on illegal drugs, drug dealing, processes of marginalization, violence, terrorism and social movements. 